\title{
Effects of nutrient intake level on mammary parenchyma growth and gene expression in crossbred (Holstein $\times$ Gyr) prepubertal heifers
}

\author{
M. M. D. C. A. Weller, ${ }^{*}$ Ronan L. Albino, ${ }^{*}$ M. I. Marcondes, ${ }^{*}$ W. Silva, ${ }^{*}$ K. M. Daniels, $†$ M. M. Campos, $\ddagger$ \\ M. S. Duarte, ${ }^{*}$ M. L. Mescouto, ${ }^{*}$ F. F. Silva, ${ }^{*}$ and S. E. F. Guimarães ${ }^{* 1}$ \\ *Animal Science Department, Universidade Federal de Viçosa, Minas Gerais, Brazil 36570-000 \\ †Dairy Science Department, Virginia Polytechnic Institute and State University, Blacksburg 24061 \\ †Embrapa Gado de Leite, Juiz de Fora, Minas Gerais, Brazil 36038-330
}

\section{ABSTRACT}

This study investigated the effects of increased nutrient intake levels on prepubertal mammary parenchyma development in crossbreed (Holstein $\times$ Gyr) dairy heifers. Eighteen heifers age 3 to 4 mo were fed 1 of 3 nutrient intake levels ( $\mathrm{n}=6$ per treatment) designed to sustain an average daily gain of $0.0 \mathrm{~kg} / \mathrm{d}$ (maintenance, MA), $0.5 \mathrm{~kg} / \mathrm{d}$ (low gain, LG), or $1.0 \mathrm{~kg} / \mathrm{d}$ (high gain, HG). Serum blood samples collected on d 42 and 84 after a 12 -h fast were analyzed for triglycerides, leptin, insulin, and insulin-like growth factor 1 (IGF-1). Liver and mammary parenchyma were biopsied on $\mathrm{d} 42$ and harvested on d 84 for gene expression analysis. Parenchyma samples were also used for biochemical and histological analysis. Mammary parenchyma weight was lower in HG than in MA or LG heifers, but mammary extraparenchymal fat was greater in HG heifers than in other groups. Heifers fed the HG diet had a greater fraction of ether extract in their parenchyma than the others and a smaller fraction of crude protein in their parenchyma than MA heifers. Moreover, the HG and LG heifers had greater body fat mass than MA heifers. Nutrient intake level had no effect on the number of intraparenchymal adipocytes. Heifers fed the HG diet had greater serum IGF-1 than the others, and serum insulin was lower in the MA than the HG or LG heifers. Liver GHR, IGF1, and IGFBP3 mRNA expression was higher, but IGFBP2 mRNA was lower in HG heifers than in others. The parenchyma mRNA expression of lipogenic markers, such as CD36, ACCA, FASN, and ADIPOR1, was upregulated by nutrient intake level. Significant nutrient intake $\times$ time interactions for lipogenic genes during the experimental period indicated variable gene expression depending on the time point of prepubertal mammary gland development. Overall, our data suggest that enhancing nutrient intake increased

Received May 30, 2016.

Accepted September 2, 2016.

${ }^{1}$ Corresponding author: sfacioni@ufv.br body fat accumulation and lipogenesis in the mammary gland to the detriment of parenchyma growth. Moreover, increased lipogenesis in the parenchyma of $\mathrm{HG}$ heifers may indicate that fat accumulation occurred because of adipocyte hypertrophy and not differences in adipogenesis. The implications of these results for milk yield needs to be elucidated.

Key words: dairy heifer, mammary lipogenesis, nutrigenomics

\section{INTRODUCTION}

It has been reported that heifer nutrition programs for weaned heifers (3 to 10 mo of age) that support an ADG of $0.7 \mathrm{~kg} / \mathrm{d}$ or more result in decreased mammary parenchymal growth (Sejrsen et al., 1982, 2000; Capuco et al., 1995) and increased extraparenchymal mammary fat deposition (Swanson, 1960; Radcliff et al., 1997). Systemic hormones (e.g., growth hormone, insulin, insulin-like growth factor-1, and leptin; Sejrsen et al., 1983; Capuco et al., 1995) and local hormones (e.g., insulin-like growth factor-1, leptin; Purup et al., 2000a; Silva et al., 2002; Meyer et al., 2007) have been examined as regulatory agents. One notion is that these hormones directly or indirectly affect not only energy and protein metabolism, but also mammary lipogenesis (Piantoni et al., 2012; Shao et al., 2013).

Much of the research conducted to date in the area of nutritional regulation of heifer mammary growth has used purebred Holstein heifers. Brazil is an emerging global leader in dairy production. Among the zebuine breeds, Gyr are particularly well adapted to Brazilian environmental conditions. For this reason, this breed has been intensely used in crosses, and is preferred for the formation of crossbred dairy herds in Brazil. Holstein $\times$ Gyr crosses account for roughly $70 \%$ of the country's milk production (Embrapa Gado de Leite, 2005). However, despite these animals' importance to the dairy industry, it is unknown whether nutrition programs developed for purebred Holsteins have the same effects in Holstein $\times$ Gyr crosses. Further, mam- 
mary composition, blood metabolite, and mammary gene expression data are lacking for Holstein $\times$ Gyr dairy heifers.

We hypothesized that increased nutrient intake by Holstein $\times$ Gyr prepubertal heifers reduces mammary parenchyma weight and increases mammary extraparenchymal fat. We further hypothesized that this occurs in concert with alterations in systemic hormone concentrations and local gene abundance changes. In this study, the expression of lipogenic enzyme genes in the parenchyma and relevant genes in the liver were of interest. We had 2 experimental objectives. The first was to confirm a detrimental effect of high nutrient intake on mammary parenchyma growth in Holstein $\times$ Gyr prepubertal heifers and to expand on previous studies by evaluating the effect of nutrient intake levels on the expression of lipogenic genes in parenchyma. The second objective was to examine the relationship between liver GHR, IGF1, IGFBP2, and IGFBP3 gene expression and prepubertal bovine mammary gland development. Identification of molecular mechanisms susceptible to different levels of nutrient intake in the mammary parenchyma of dairy heifers can help us better understand mammary gland development during the allometric phase and, in the future, suggest appropriate nutritional management to maximize milk production.

\section{MATERIALS AND METHODS}

All animal care and handling procedures followed regulations approved by the Institutional Animal Welfare and Ethics/Protection Commission (certificate number 47/2012) from the Universidade Federal de Viçosa, Minas Gerais, Brazil. The experiment was performed outdoors at the Universidade Federal de Viçosa from March to July 2015.

\section{Experimental Design and Animal Management}

Eighteen crossbred (Holstein $\times$ Gyr) heifers with an average initial BW of $102.2 \pm 3.4 \mathrm{~kg}$ and age 3 to 4 mo used. Heifers were individually housed and fed for the duration of the 84-d experiment. The experimental unit was the heifer. Before the start of the experiment, all heifers were allowed ad libitum access to a corn silagebased diet for $10 \mathrm{~d}$ to minimize potential compensatory gain effects during the treatment period. Then, heifers were assigned in a completely randomized design to 1 of 3 nutrient intake levels $(\mathrm{n}=6$ per treatment) designed to sustain an ADG of $0.0 \mathrm{~kg} / \mathrm{d}$ (maintenance, MA), 0.5 $\mathrm{kg} / \mathrm{d}$ (low gain, LG), or $1.0 \mathrm{~kg} / \mathrm{d}$ (high gain, HG). It is well documented that Holstein heifers from 3 to 10 mo of age fed to achieve growth rates above $0.7 \mathrm{~kg} / \mathrm{d}$ have impaired mammary growth, but no studies have been
Table 1. Composition of ingredients and nutrients in the experimental diet

\begin{tabular}{lc}
\hline Item & \% of DM \\
\hline Ingredient & \\
Corn silage & 59 \\
Corn & 22.3 \\
Soybean meal & 9.4 \\
Bypass protein soybean meal & 7.7 \\
Urea & 0.3 \\
Mineral mix ${ }^{1}$ & 1.2 \\
Nutrient & \\
CP & 18.3 \\
NDF & 34 \\
NFC & 39.8 \\
TDN & 73.6 \\
Ether extract & 2.2 \\
\hline
\end{tabular}

${ }^{1}$ Supplement contained, per kilogram: limestone $40 \mathrm{~g}$, flower of sulfur $15 \mathrm{~g}$, dicalcium phosphate $15 \mathrm{~g}$, potassium iodate $4 \mathrm{mg}$, zinc sulfate $0.2 \mathrm{mg}$, copper sulfate $60 \mathrm{mg}$, cobalt sulfate $1.5 \mathrm{mg}$, manganese sulfate $5 \mathrm{mg}$, sodium selenite $1 \mathrm{mg}$.

performed on crossbred (Holstein $\times$ Gyr) prepubertal heifers. Thus, we choose nutrient intake levels that sustained an ADG below (LG, $0.5 \mathrm{~kg} / \mathrm{d}$ ) and above (HG, $1 \mathrm{~kg} / \mathrm{d}$ ) this value. The maintenance group was used as reference. All heifers were fed equal portions of the assigned diet twice daily at 0800 and $1600 \mathrm{~h}$ throughout the experiment (Table 1). The HG diet was formulated based on the ME requirements of large-breed dairy heifers weighing $150 \mathrm{~kg}$ and gaining $1.0 \mathrm{~kg} / \mathrm{d}$ of BW (NRC, 2001). Feed intake for the LG diet was adjusted to support an ADG of $0.5 \mathrm{~kg} / \mathrm{d}$; the same was done for MA so that initial BW was maintained throughout the experiment. All heifers were weighed every $14 \mathrm{~d}$; DMI adjustments were made every $14 \mathrm{~d}$ before the morning feeding.

\section{Blood Sampling and Analysis}

Jugular blood samples were collected from each heifer ( $\mathrm{n}=18$ ) before the morning feeding (after 12-h fast) on d 42 and 84 of the experiment. Blood was collected into evacuated serum tubes. All samples were kept on ice after collection and transported into the laboratory within $1 \mathrm{~h}$. Immediately after arrival at the laboratory, the $10-\mathrm{mL}$ tubes were centrifuged at $1,340 \times g$ at $4^{\circ} \mathrm{C}$ for $15 \mathrm{~min}$ to obtain the serum; 3 aliquots $(1 \mathrm{~mL}$ each) of serum were individually labeled and frozen at $-20^{\circ} \mathrm{C}$. Subsequently, serum triglycerides, leptin, insulin, and IGF-1 concentrations were measured. Serum triglycerides were determined using a colorimetric assay kit (Cayman Chemical, Ann Arbor, MI). The intra- and interassay CV for serum triglycerides were less than $5 \%$ and $7 \%$, respectively. Serum leptin was analyzed using an ELISA kit (Diagnostics Biochem Inc., Dorchester, ON, Canada). The intra- and interassay CV for serum leptin were less than $4 \%$ and $5 \%$, respectively. The IGF1 
concentrations were determined with a chemiluminescence assay (Immulite 2000 IGF1, Siemens Healthcare Diagnostics Products Ltd., Gwynedd, UK). The IGFbinding proteins were not extracted before analysis. The intra- and interassay CV for serum IGF-1 were less than $4 \%$ and $3 \%$, respectively. Serum insulin was determined using an immunochemiluminescence assay kit (Abbott Japan Company Ltd., Tokyo, Japan). Intra- and interassay CV for serum insulin were less than $6 \%$ and $7 \%$, respectively.

\section{Tissue Sampling}

We obtained liver and mammary parenchyma biopsies on d 42 from 3 heifers per treatment, chosen randomly. Animals were fasted for $12 \mathrm{~h}$ before biopsy procedures and were lightly sedated with a single $0.5 \mathrm{~mL}$ intravenous injection of xylazine. Heifers were placed in a squeeze chute for liver biopsy tissue collection. Liver biopsy sites were clipped and cleaned with $70 \%$ ethanol. Five milliliters of lidocaine was administered subcutaneously near the biopsy site. Aseptic technique was used, and a 1-cm incision was made with a scalpel between the 11th and 12th ribs on a line from the tuber coxae to the point of the shoulder. Liver biopsies $(\sim 50$ $\mathrm{mg}$ ) were obtained from the right lobe using the truecut technique described by Pearson and Craig (1980). For mammary biopsies, heifers were placed in lateral recumbency with restraint. The area to be biopsied was clipped and cleaned with $70 \%$ ethanol. Ten milliliters of lidocaine was administered subcutaneously near the biopsy site. Aseptic technique was used, and a $2 \mathrm{~cm}$ incision was made through the skin glands. Mammary parenchyma biopsies $(\sim 50 \mathrm{mg})$ were obtained from the mid-parenchyma region of each left gland as described by Farr et al. (1996). Biopsy samples were immediately immersed in $5 \mathrm{~mL}$ of RNAholder (BioAgency, São Paulo, Brazil). Liver biopsies always preceded mammary biopsies. After $24 \mathrm{~h}$, the collected tissues were removed from RNAholder, drained, and stored at $-80^{\circ} \mathrm{C}$ until RNA extractions were carried out.

All heifers were slaughtered on d 84 by captive bolt stunning followed by exsanguination; animals were fasted for $12 \mathrm{~h}$ before slaughter. Liver samples obtained at slaughter were from the right lobe of each heifer's liver. For mammary sampling at slaughter, the whole udder was removed, weighed, skinned, and bisected into right and left halves at the median suspensory ligament. Then, the skinned right and left hemi-udders were dissected to collect parenchyma tissue. The weight of the parenchyma tissue was recorded after extraparenchymal fat and lymph nodes were removed. The weight of MEF was also recorded. The left skinned hemi-udders were used to obtain samples from the mid-parenchyma region for RNA extraction; the right skinned hemi-udders were used to obtain samples from the mid-parenchyma region for biochemical and histological analyses (described below). The samples of liver and mammary parenchyma collected for RNA analysis were immediately immersed in $5 \mathrm{~mL}$ of RNAholder, and the archiving procedure described above for the biopsy samples was employed.

The carcasses were stored in a cold chamber at $4^{\circ} \mathrm{C}$ for $24 \mathrm{~h}$; whole carcasses were then completely ground in a meat grinder. A single sample from each ground carcass was taken and stored at $-20^{\circ} \mathrm{C}$. Later, samples were removed from the freezer, lyophilized, and then further ground with a knife mill. Next, samples were subjected to analysis for body fat mass (ether extract; method 920.85; AOAC, 1990).

\section{Biochemical Analysis of Parenchyma}

Dissected parenchyma samples were lyophilized before analysis. The samples were analyzed for CP (method 920.87; AOAC, 1990) and ether extract content (method 920.85; AOAC, 1990).

\section{Histological Analysis of Parenchyma}

Formalin-fixed parenchyma samples were dehydrated in increasing concentrations of ethanol $\left(70^{\circ} \mathrm{C}, 95^{\circ} \mathrm{C}\right.$, and $100^{\circ} \mathrm{C}$ ), cleared in Histochoice (Sigma-Aldrich, St. Louis, MO), and embedded in Paraplast (Sigma-Aldrich). Blocks were sectioned serially at a thickness of $10 \mu \mathrm{m}$ and stained with hematoxylin-eosin.

After qualitative evaluation of the slides, 10 randomly selected digital images of parenchyma were obtained for each heifer. For this, we used a camera (AxioCam HRc; Zeiss, Göttinger, Germany) linked to a light microscope (AX-70 TRF; Olympus Optical, Tokyo, Japan) at $10 \times$ magnification (Figure 1 ). The resultant images were analyzed with ImageJ 1.48 software (National Institutes of Health, Bethesda, MD). The number of intraparenchymal adipocytes was manually counted in each image, and then the average intraparenchymal adipocyte number was calculated for each animal before statistical analyses. We measured the proportion of mammary epithelial cells in the parenchymal tissue by counting points in the 10 digital images described above. Briefly, a grid of 315 evenly distributed test points was superimposed over the screen image of every digital image. In each animal, the number of test points overlying mammary epithelial cells was counted; with this method, a higher number of points equated to more mammary epithelial cells. 

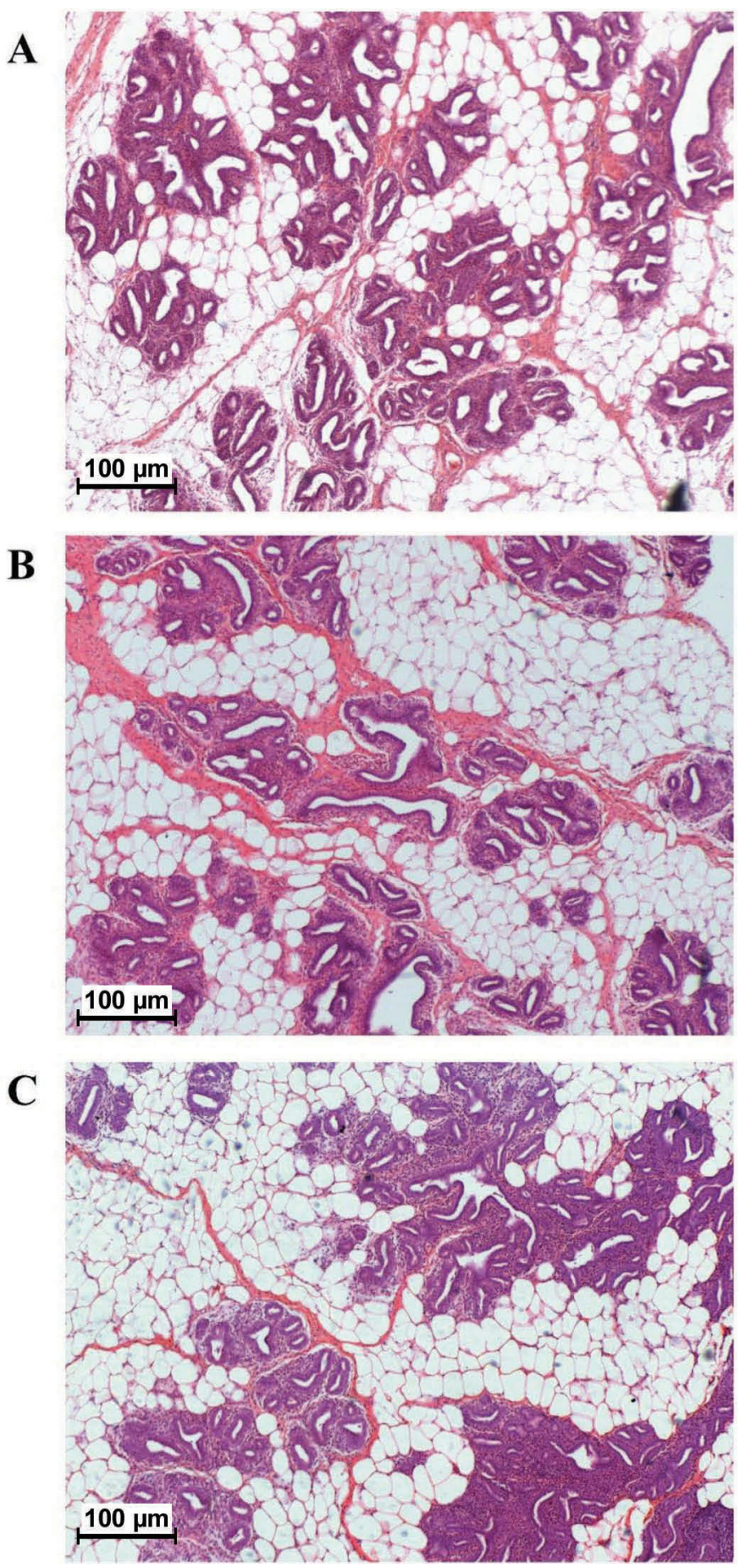

Figure 1. Representative mammary parenchymal images from the (A) maintenance, (B) high gain, and (C) low gain heifers at slaughter (84 d). Scale bar $=100 \mu \mathrm{m}$. Color version available online.

\section{Quantitative Real-Time Transcription PCR}

Total RNA was isolated from $30 \mathrm{mg}$ of liver and parenchyma tissue using the Trizol method (Invitrogen, Carlsbad, CA; https://tools.thermofisher.com/con- tent/sfs/manuals/trizol_reagent.pdf). We performed additional treatment with DNase on the columns using the RNase-free DNase Set (Qiagen), according to the manufacturer's instructions (https://www.qiagen.com/ us/resources/resourcedetail?id=b0ca9e5a-ff87-476e811b-ff80e4f07b3f\&lang=en). We determined RNA concentration, purity, and integrity with an Agilent RNA 6000 Nano Kit using the Agilent 2100 Bioanalyzer (Agilent Technologies Inc., Mississauga, ON, Canada). The average RNA integrity number was 7.5.

We performed reverse transcription using the GoScript Reverse Transcription System (Promega, Madison, WI) and random primers (Invitrogen, Carlsbad, $\mathrm{CA}$ ). The cDNA concentrations from the samples were estimated on a NanoVue Plus spectrophotometer (GE Healthcare, Munich, Germany). Finally, the cDNA samples were aliquoted and stored at $-20^{\circ} \mathrm{C}$ before analysis.

Quantitative real-time PCR (qRT-PCR) was performed in different wells and in triplicate using SYBR Green detection, with GoTaq PCR Master Mix (Promega) following the manufacturer's instructions (https://www.promega.com.br/resources/protocols) in an ABI Prism 7300 Sequence Detection System thermocycler (Applied Biosystems, Waltham, MA). Each reaction consisted of an initial step at $95^{\circ} \mathrm{C}$ for $10 \mathrm{~min}$, a second step of 40 cycles at the same temperature for $15 \mathrm{~s}$, and a final extension step at $60^{\circ} \mathrm{C}$ for $60 \mathrm{~s}$. After the amplification cycles, an additional gradient step from $60^{\circ} \mathrm{C}$ to $95^{\circ} \mathrm{C}$ was used to obtain a melting curve. Measurement in qRT-PCR is expressed in cycles to threshold $(\mathbf{C t})$ of $\mathrm{PCR}$, a relative value that represents the cycle number at which the amount of amplified cDNA reaches the threshold level. Prior to quantification by qRT-PCR, primer efficiencies for internal control and target genes were determined using 4 dilutions of liver and parenchyma cDNA according to the following equation: $\%$ efficiency $=10^{(-1 / \text { slope })} \times$ 100 , where slope was the gradient of the dilution series. Primer efficiencies were approximately equal for target and internal control genes, and averaged $98 \%$. The CV of $\mathrm{Ct}$ values from replicates in each sample was less than 5\%, indicating acceptable accuracy and reproducibility (data not shown). Expression was considered undetectable in samples with $\mathrm{Ct}$ values greater than 36 based on inconsistent amplification (low efficiency) beyond this cycle threshold (Bustin et al., 2009).

We recovered target and internal control gene sequences from Bos taurus nucleotide sequences obtained from the GenBank database (http://www.ncbi.nlm. nih.gov/gene). The following genes were measured in parenchyma: $O b-R b, C D 36, A C C A, F A S N$, and $A D I-$ POR1. In liver samples, GHR, IGF1, IGF1R, IGFBP3, and $I G F B P 2$ genes were measured. Specific primers 
Table 2. Gene name, primer pair sequences, annealing temperature and amplification efficiency of each target



${ }^{1}$ Genes: leptin receptor $(O b-R b)$, trombospondin receptor $(C D 36)$, acetyl-CoA carboxylase $\alpha(A C C A)$, fatty acid synthase $(F A S N)$, adiponectin receptor 1 (ADIPOR1), growth hormone receptor $(G H R)$, insulin-like growth factor $1(I G F 1)$, insulin-like growth factor 1 receptor $(I G F 1 R)$, insulin-like growth factor binding protein 2 (IGFBP2), insulin-like growth factor binding protein 3 (IGFBP3), mitochondrial GTPase 1 (MTG1), ribosomal protein S15a $(R S P 15 A)$, protein phosphatase-1 inhibition subunit (PPP1R11), glyceraldehyde 3-phosphate dehydrogenase (GAPDH), $18 \mathrm{~S}$ ribosomal RNA $(18 S)$, and B-actin $(A C T B)$.

${ }^{2}$ GenBank (http://www.ncbi.nlm.nih.gov).

were developed using PrimerQuest software (Integrated DNA Technologies Inc., Coralville, IA). The primer pairs for each target and internal control genes are listed in Table 2. In the present study, the genes used for normalization in parenchyma were mitochondrial GTPase 1 (MGT1), ribosomal protein S15a (RSP15A), and protein phosphatase-1 inhibition subunit 11 (PPP1R11). These same genes were deemed the most suitable as control genes for normalization of qRT-PCR data from prepubertal bovine mammary tissue (Piantoni et al., 2008). The genes used for normalization in liver were glyceraldehyde 3-phosphate dehydrogenase (GAPDH), $18 \mathrm{~S}$ ribosomal RNA (18S), and $\beta$-actin $(A C T B)$. The normalization factor was calculated as the geometric mean of the control genes' Ct values for each sample (Vandesompele et al., 2002). The relative mRNA abundance of target genes for each heifer was determined by subtracting the $\mathrm{Ct}$ value for the geometric mean of the control genes from the target gene $\mathrm{Ct}\left(\mathrm{Ct}_{\text {target }}-\right.$
$\left.\mathrm{Ct}_{\text {geometric mean control genes }}\right)$. Relative expression values were estimated as $2^{-\Delta \mathrm{Ct}}$ (Livak and Schmittgen, 2001).

\section{Statistical Analysis}

Before performing statistical analysis, we tested the normality of the variables and found that they were normally distributed. All data were analyzed using the mixed procedure in SAS (version 9.3; SAS Institute Inc., Cary, NC). We included nutrient intake level, day of experiment (42 and $84 \mathrm{~d}$ ), and their interaction as fixed effects and heifer as a random effect. Hormone concentrations and qRT-PCR analyses included day of experiment as a repeated measure, considering animal as the subject. The qRT-PCR data submitted to SAS consisted of $2^{-\Delta \mathrm{Ct}}$ values. Means were tested using the LSMEANS option in SAS and were considered significant when $P \leq 0.05$ and a tendency when $0.05 \leq P$ $\leq 0.10$. We used the Pearson correlation procedure in 
SAS to determine the relationships between selected variables.

\section{RESULTS}

\section{Metabolites and Hormone Concentrations}

We observed no interaction between nutrient intake level and day of experiment for serum triglycerides $(P$ $=0.137)$, insulin $(P=0.325)$, leptin $(P=0.190)$, or IGF-1 $(P=0.726$, Table 3$)$. We also observed no effect of nutrient intake level $(P=0.117)$ or day of experiment $(P=0.250)$ for serum triglycerides. Nutrient intake level did affect serum insulin concentration $(P=0.014$, Table 3). As well, the amount of insulin decreased $(P$ $=0.002$ ) over the day of experiment. Serum leptin concentrations tended to increase across nutrient intake levels $(P=0.061)$ with no effect of day of experiment $(P=0.147)$. Serum IGF-1 concentrations were greater $(P<0.001$, Table 3$)$ in HG heifers than in LG or MA heifers. In addition, the amount of IGF-1 increased ( $P$ $=0.017$ ) over the day of experiment.

\section{Body Growth and Mammary Gland Development}

Initial BW was not different between treatments $(P$ $=0.721)$. As intended, nutrient intake levels affected ADG; $P<0.001)$ and final BW $(P<0.001)$. Body fat mass was increased in heifers fed the HG and LG diets compared with the MA diet, but body fat mass was similar between HG and LG heifers $(P=0.014$, Table 4).

Mammary gland weight and mammary extraparenchymal fat weight were greater $(P<0.001)$ in $\mathrm{HG}$ and LG than in MA heifers (Table 4$)$. Mammary parenchyma weight was lower $(P=0.037)$ in $\mathrm{HG}$ and MA than in LG heifers; the lowest value was observed in MA heifers. Nutrient intake level affected the lipid $(P$ $=0.009)$ and $\mathrm{CP}$ content $(P=0.008)$ of mammary parenchyma. Heifers fed the HG diet retained more lipids in their mammary parenchyma than the MA and LG heifers. However, HG and LG heifers retained less protein in their mammary parenchyma than MA heifers. We observed no differences in the number of intraparenchymal adipocytes $(P=0.570)$ between nutrient intake levels.

\section{Liver Gene Expression}

We observed no interaction between nutrient intake level and day of experiment for IGFR1 (Figure 2). Also, we detected no differences in the expression of transcripts for $I G F 1 R$ due to nutrient intake level $(P$ $=0.193)$ or day of experiment $(P=0.132)$. However,

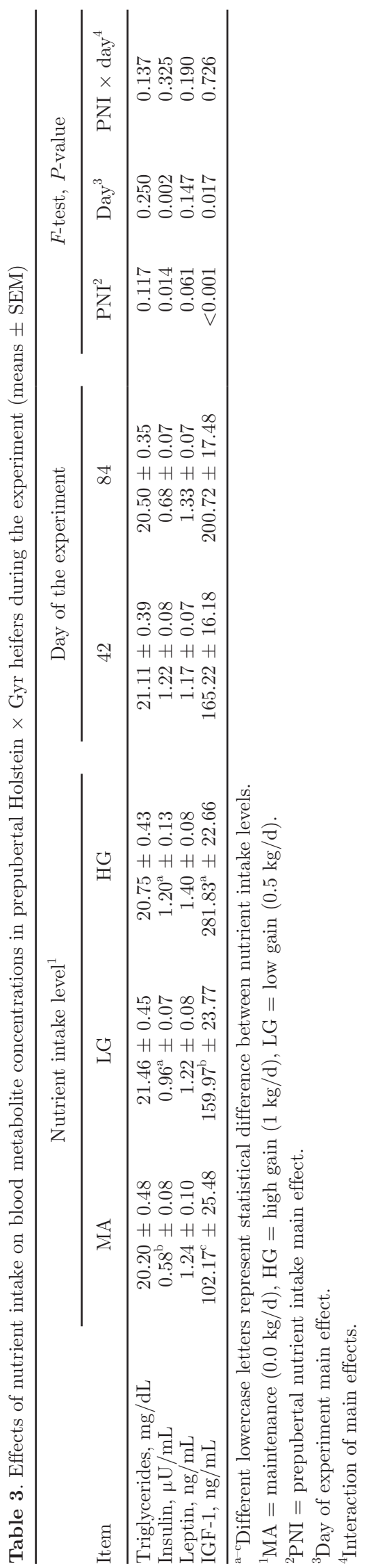

Journal of Dairy Science Vol. 99 No. 12, 2016 
Table 4. Effects of nutrient intake on DMI, final BW, ADG, and mammary parenchyma development in prepubertal Holstein $\times$ Gyr heifers (means $\pm \mathrm{SEM}$ )

\begin{tabular}{|c|c|c|c|c|}
\hline \multirow[b]{2}{*}{ Item } & \multicolumn{3}{|c|}{ Prepubertal nutrient intake ${ }^{1}$} & \multirow[b]{2}{*}{$P$-value } \\
\hline & MA & $\mathrm{LG}$ & $\mathrm{HG}$ & \\
\hline Initial BW, $\mathrm{kg}$ & $98.16 \pm 6.08$ & $104.33 \pm 6.08$ & $104.17 \pm 6.08$ & 0.721 \\
\hline DMI, kg & $1.48 \pm 0.75$ & $2.56 \pm 0.75$ & $3.78 \pm 0.75$ & $<0.001$ \\
\hline Final BW, kg & $107^{\mathrm{c}} \pm 7.30$ & $146.33^{\mathrm{b}} \pm 7.30$ & $181.20^{\mathrm{a}} \pm 7.99$ & $<0.001$ \\
\hline $\mathrm{ADG}, \mathrm{kg} / \mathrm{d}$ & $0.105^{\mathrm{c}} \pm 0.02$ & $0.500^{\mathrm{b}} \pm 0.02$ & $0.907^{\mathrm{a}} \pm 0.02$ & $<0.001$ \\
\hline Body fat mass, $\mathrm{g} / \mathrm{kg}$ of $\mathrm{BW}$ & $331.2^{\mathrm{b}} \pm 13.58$ & $390^{\mathrm{a}} \pm 14.87$ & $395.7^{\mathrm{a}} \pm 16.63$ & 0.014 \\
\hline Mammary gland weight, $\mathrm{kg}$ & $0.621^{\mathrm{b}} \pm 111.2$ & $1.210^{\mathrm{a}} \pm 111.2$ & $1.405^{\mathrm{a}} \pm 111.2$ & $<0.001$ \\
\hline Mammary extraparenchymal fat weight, $\mathrm{kg}$ & $0.313^{\mathrm{c}} \pm 0.68$ & $0.603^{\mathrm{b}} \pm 0.75$ & $1.027^{\mathrm{a}} \pm 0.75$ & $<0.001$ \\
\hline Mammary parenchyma weight, $\mathrm{kg}$ & $0.178^{\mathrm{b}} \pm 0.40$ & $0.356^{\mathrm{a}} \pm 0.44$ & $0.237^{\mathrm{b}} \pm 0.44$ & 0.037 \\
\hline $\mathrm{CP}, \mathrm{g} / \mathrm{kg}$ of mammary parenchyma & $128.7^{\mathrm{a}} \pm 6.95$ & $109.7^{\mathrm{b}} \pm 6.95$ & $91.90^{\mathrm{b}} \pm 6.95$ & 0.009 \\
\hline Lipid, $\mathrm{g} / \mathrm{kg}$ of mammary parenchyma & $861.1^{\mathrm{b}} \pm 7.35$ & $878.7^{\mathrm{b}} \pm 7.35$ & $900.7^{\mathrm{a}} \pm 7.35$ & 0.008 \\
\hline No. of intraparenchymal adipocytes & $451.95 \pm 67.46$ & $357.62 \pm 55.08$ & $397.42 \pm 55.08$ & 0.570 \\
\hline Mammary epithelium, \% & $24.494 \pm 4.61$ & $33.873 \pm 4.61$ & $26.492 \pm 4.61$ & 0.344 \\
\hline
\end{tabular}

${ }^{a-c}$ Means within a row with different superscripts differ $(P<0.05)$.

${ }^{1} \mathrm{MA}=$ maintenance $(0.0 \mathrm{~kg} / \mathrm{d}), \mathrm{HG}=$ high gain $(1.0 \mathrm{~kg} / \mathrm{d}), \mathrm{LG}=$ low gain $(0.5 \mathrm{~kg} / \mathrm{d})$.

nutrient intake level altered the relative mRNA abundance of $G H R(P<0.001)$, IGF1 $(P=0.008), I G F B P 2$ $(P=0.047)$, and IGFBP3 $(P=0.036)$. We observed an interaction between nutrient intake level and day of experiment on the relative mRNA abundance of GHR $(P=0.007), \operatorname{IGF1}(P=0.014)$, and IGFBP3 $(P=0.027)$, but not for IGFBP2 $(P=0.144)$. We observed higher mRNA abundance of GHR, IGF1, and IGFBP3 in HG heifers, on both experiment days (Figure 2). We observed similar expression of GHR, IGF1, and $I G F B P 3$ genes in MA and LG heifers. In contrast, $I G F B P 2$ mRNA abundance was lower in $\mathrm{HG}$ heifers than in MA heifers.

\section{Mammary Gene Expression}

Messenger RNA for the long receptor isoform ( $\mathrm{Ob}$ $R b$ ) was not readily detectable in the parenchyma, although inclusion of liver mRNA as a positive control verified the ability of the primer to amplify a single product of the expected size (data not shown). Most of the parenchyma samples failed to reach threshold amplification after 37 cycles of PCR. This indicated that the fully competent $O b-R b$ isoform was absent or at low levels in heifers' mammary parenchyma at this age, as previously reported (Silva et al., 2002; Thorn et al., 2006). The $O b-R b$ data were not analyzed, were labeled undetectable, and are not discussed further.

Nutrient intake level affected the relative mRNA abundance of $C D 36(P<0.001), A C C A(P=0.034)$, FASN $(P=0.041)$, and ADIPOR $1(P=0.048)$. We observed an interaction between nutrient intake and day of experiment on the relative mRNA abundance of CD36 $(P<0.001), A C C A(P=0.036), F A S N(P=$ $0.014)$, and $A D I P O R 1(P=0.012)$. Mammary parenchyma from HG heifers had higher $(P<0.05)$ expres- sion of these genes than LG and MA heifers at $42 \mathrm{~d}$ (Figure 3).

\section{Correlations}

Across all nutrient intake levels, average serum IGF-1 concentration (across days) was positively correlated with the relative abundance of liver IGF1 mRNA $(\mathrm{r}=$ $0.80, P=0.001)$ and IGFBP 3 mRNA $(\mathrm{r}=0.76, P=$ $0.015)$. On the other hand, serum IGF-1 concentration was negatively correlated with IGFBP2 mRNA ( $\mathrm{r}=$ $-0.50, P=0.025)$ in liver, but unrelated to parenchyma weight. Parenchyma weight was negatively correlated with the relative abundance of $I G F B P 3 \mathrm{mRNA}$ in liver $(\mathrm{r}=-0.64, P=0.007)$. Moreover, the lipid content of parenchyma was positively correlated with the relative abundance of $A C C A(\mathrm{r}=0.78, P<0.001)$ and $C D 36$ mRNA $(\mathrm{r}=0.62, P=0.012)$.

\section{DISCUSSION}

Earlier studies have focused largely on establishing a direct link between high-energy, high-protein diets $(\mathrm{ADG}>0.7 \mathrm{~kg} / \mathrm{d})$ and impaired development of mammary gland in prepubertal Holstein heifers (Sejrsen et al., 1982; Capuco et al., 1995; Radcliff et al., 1997). However, the effects of high nutrient intake on mammary gland development, liver GHR-IGF1-IGFBP axis gene expression, and their relationship with mammary gland development are scarce. Moreover, despite the importance of Holstein $\times$ Gyr dairy heifers to Brazil's dairy industry, it is generally unknown how different nutritional programs affect mammary growth in these crossbred animals. In this context, we choose 2 nutrient intake levels that sustained an ADG below (LG, $0.5 \mathrm{~kg} / \mathrm{d})$ and above $(\mathrm{HG}, 1 \mathrm{~kg} / \mathrm{d})$ the reference value 
$(\mathrm{ADG}=0.7 \mathrm{~kg} / \mathrm{d})$ for prepubertal Holsteins. The data from the present study provide evidence that elevated nutrient intake can induce changes in the expression of lipogenic genes in mammary parenchyma, leading to increased lipogenesis in intraparenchymal adipocytes but no alterations in their numbers in prepubertal bovine mammary glands. Furthermore, we demonstrated that increasing nutrient intake levels in prepubertal heifers altered the concentrations of hormones involved with nutritive status and liver GHR-IGF1-IGFBP axis mRNA expression. We speculate, but did not directly demonstrate, that these endocrine and hepatic gene expression alterations were the trigger for observed changes in mammary gland development in Holstein $x$ Gyr prepubertal heifers.

Blood metabolites are accepted indicators of nutritive and metabolism status. Thus, we sought to measure circulating triglycerides, insulin, leptin, and IGF-1 as indices of lipid and energy metabolism in heifers fed different nutrient intake levels to associate this nutritional relationship with changes to mammary gland development. We chose to sample blood after a $12-\mathrm{h}$ fast to reflect baseline triglycerides, insulin, leptin, and IGF-1, rather than a meal response. Serum triglycerides were not affected by nutrient intake level. Although triglycerides were not as useful as non-esterified fatty
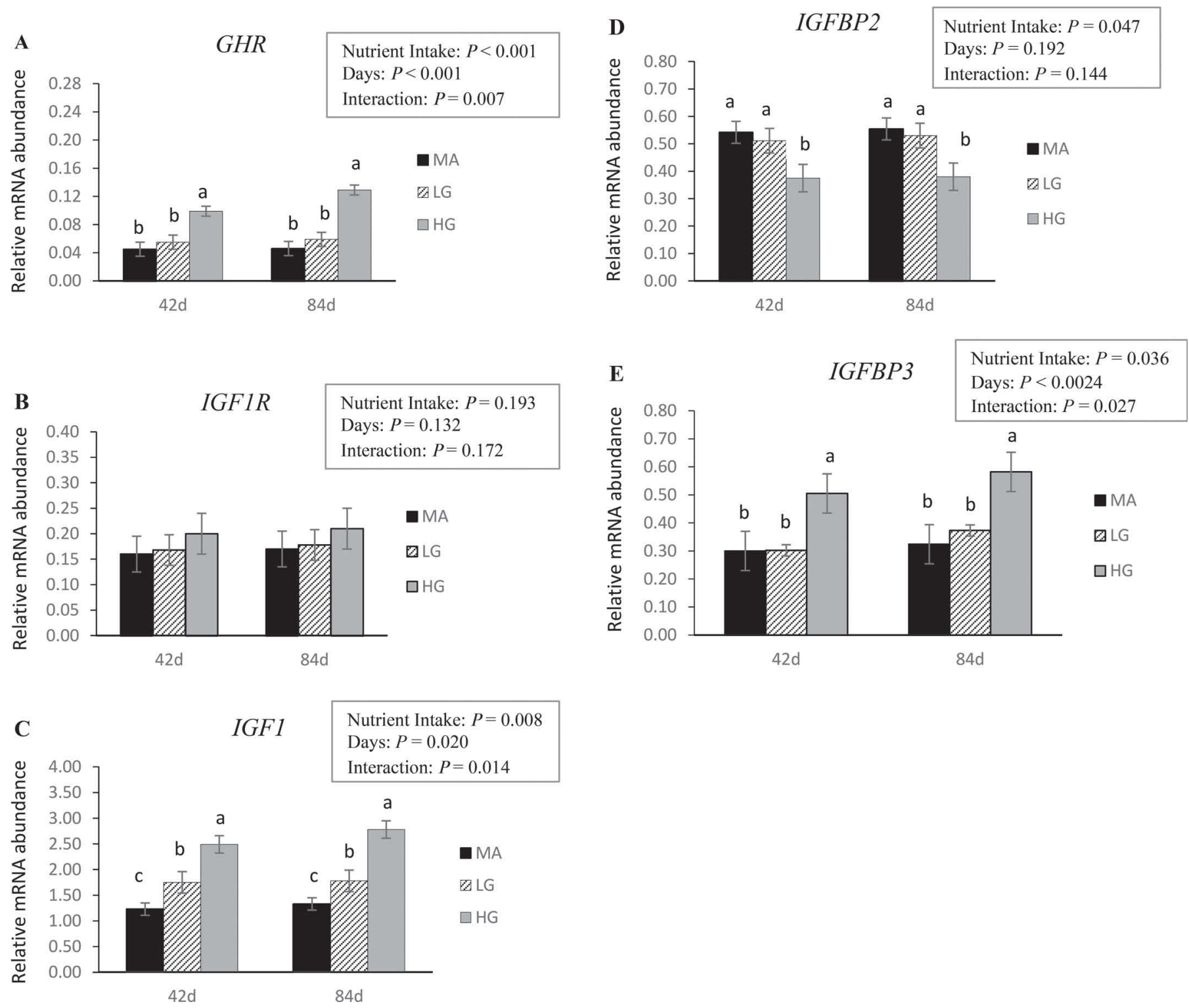

Figure 2. Comparative relative mRNA abundance of (A) GHR, (B) IGF1R, (C) IGF1, (D) IGFBP2, and (E) $I G F B P 3$ in liver from prepubertal heifers fed 1 of 3 nutrient intakes (maintenance, MA; low gain, LG; and high gain, HG) throughout the experiment. Relative mRNA abundance is expressed as LSM $\pm 2^{-\Delta \mathrm{Ct}}$. Different letters represent differences $(P<0.05)$ between nutrient intakes within the day of experiment. 
acids to determine fat metabolism, the lack of diet effects on serum triglycerides may be indicative that feed intake in all treatments provided sufficient energy for the maintenance of heifer $\mathrm{BW}$ in the MA group and planned ADG in the HG and LG groups, likely without fat mobilization.

Previous studies have reported that elevated nutrient intake increased leptin concentrations (Block et al., 2003; Davis Rincker, 2005; Thorn et al., 2006). In addition, Delavaud et al. (2000) observed that increased body fat increased leptin production. In our study, the heifers fed HG had more fat and their serum leptin concentrations tended to be higher than those of MA and LG heifers. These results are in general agreement with other reports in ruminants, where circulating leptin concentrations were strongly related to body fat and positively related to feeding level (Delavaud et al., 2002; Thorn et al., 2006).

In the present study, we observed that enhanced nutrient intake levels resulted in increased body fat mass, and in mammary gland and extraparenchymal fat weight in prepubertal Holstein $\times$ Gyr heifers. Our results are in agreement with previous studies conducted in purebred Holstein heifers, where it was found that high-energy diets increased body fat deposition and extraparenchymal mammary fat (Stelwagen and
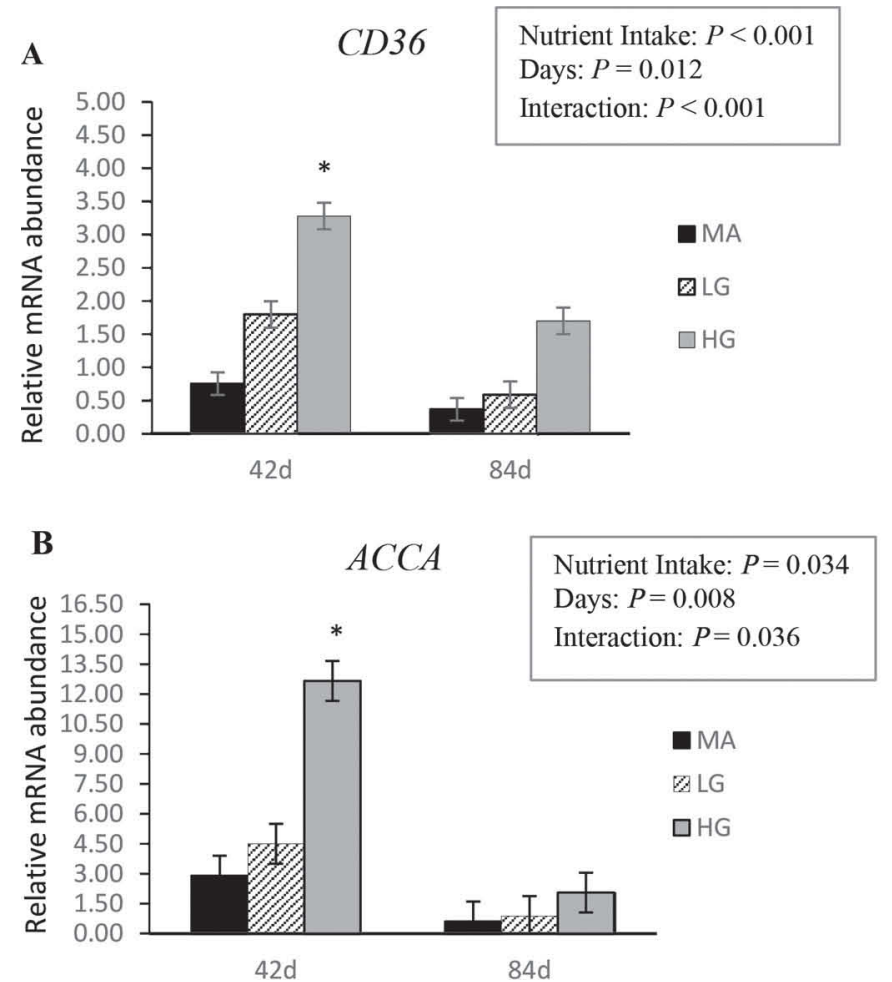

Grieve, 1990; Radcliff et al., 1997) and impaired parenchyma growth (Sejrsen et al., 1982, 2000; Capuco et al., 1995). In addition, increased body fat mass in prepubertal heifers has been associated with decreased mammogenesis (Silva et al., 2002). These observations and our results reinforce the hypothesis that elevated nutrient intake in weaned heifers favors the accumulation of fat in the mammary gland and is detrimental to the growth of parenchyma.

It is well known that IGF-1 mediates the mammogenic action of growth hormone via endocrine, paracrine, or autocrine mechanisms (Forsyth, 1996; Weber et al., 1999; Purup et al., 2000a). The majority of serum IGF1 is produced by the liver through IGF-1 gene expression, which is controlled by growth hormone and insulin (Phillips et al., 1991; Eleswarapu et al., 2008). Purup et al. (2000b) reported a strong correlation between serum IGF-1 and IGF-1 from mammary extracts $(\mathrm{r}=$ 0.84 ), suggesting that IGF-1 concentrations in mammary tissue depend on the concentration of IGF-1 in blood. Similar to previous studies (Capuco et al., 1995; Radcliff et al., 1997, 2004), we observed that serum insulin and IGF-1 concentration increased in response to augmented nutrient intake levels. Because insulin regulates mechanisms of partitioning nutrients toward body tissues and systemic IGF-1, we can infer that increased
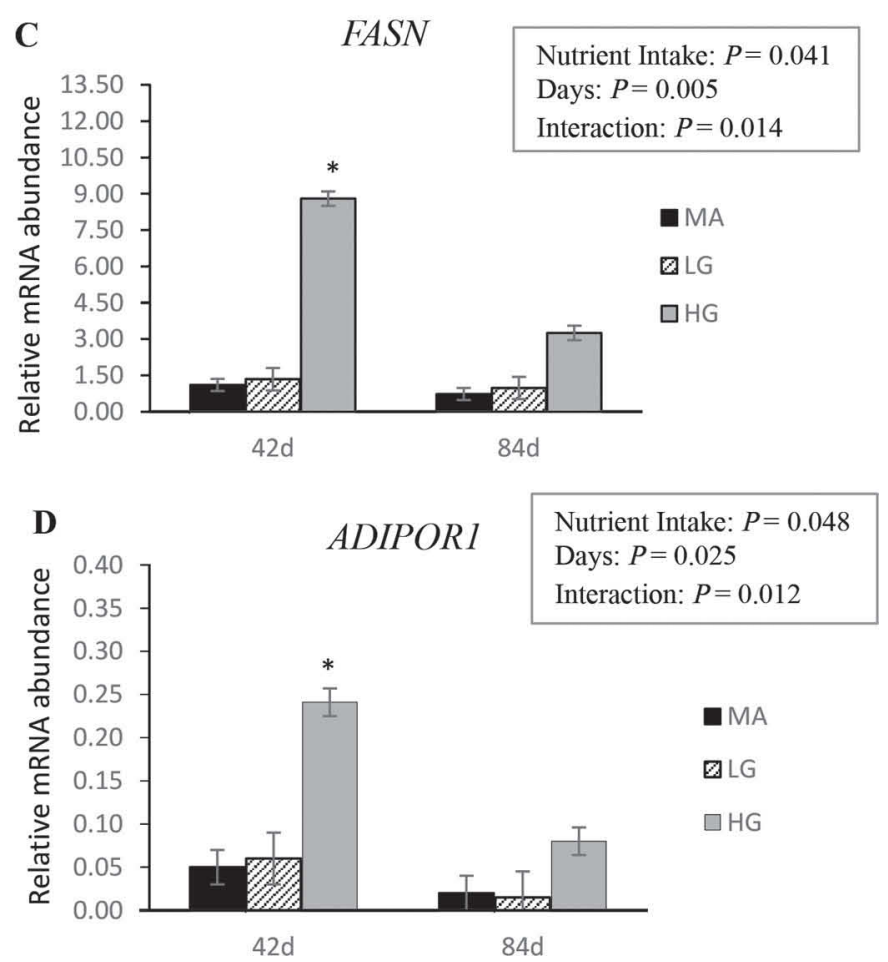

Figure 3. Comparative relative mRNA abundance of (A) CD36, (B) ACCA, (C) FASN, and (D) ADIPOR1 in mammary parenchyma from prepubertal heifers fed 1 of 3 nutrient intakes (maintenance, MA; low gain, LG; and high gain, HG) within the day of experiment. Relative mRNA abundance is expressed as LSM $\pm 2^{-\Delta \mathrm{Ct}}$. $* P<0.05$ compared with MA and LG heifers at $42 \mathrm{~d}$ of experiment. 
IGF-1 in HG heifers could be mediated by an increase in insulin concentration. Moreover, we observed that the greater serum IGF-1 concentrations in HG heifers was strongly associated with greater liver IGF1 mRNA. The positive correlation between liver IGF1 mRNA and serum IGF-1 concentrations illustrates the dependence of systemic IGF-1 on liver IGF-1 synthesis (Sharma et al., 1994; Yakar et al., 1999).

Previous studies have reported that feeding heifers a high-energy diet increased liver growth hormone receptor (Capuco et al, 1995; Smith et al., 2002). Although we did not measure serum growth hormone concentration in our study, HG heifers had greater liver GHR mRNA. Binding of growth hormone to isolated hepatic membranes is highly correlated with GHR mRNA expression (Radcliff et al., 2003). Also, an increase in the relative mRNA abundance of GHR increased the capacity of the liver for growth hormone binding and increased growth hormone-dependent responses such as IGF-1 synthesis and release (Radcliff et al., 2004). It is also reasonable to assume that increasing liver $G H R$ mRNA in HG heifers could be mediated by the increase in serum insulin concentrations in these heifers and a subsequent increase in nuclear factors controlling liverspecific genes, such as GHR. For instance, loss of insulin or reduction in human hepatic insulin sensitivity caused a reduction in GHR mRNA (Schwartzbauer and Menon, 1998). Moreover, Butler et al. (2003) reported that insulin infusion increased GHR mRNA and IGF1 mRNA in the liver of postpartum dairy cows.

In some respects, it seems contradictory that HG heifers had lower parenchyma weight than LG heifers, even though they had greater serum IGF-1 concentrations. This contradictory effect can probably be explained by changes in IGF-binding proteins. The bioavailability of IGF-1 is modulated by a group of IGF-binding proteins, IGFBP1-6, that regulate circulating IGF-1 concentrations and action (Firth and Baxter, 2002). Nutrient intake is a major regulator of the biological action of IGF-1 through changes in IGFBP (Smith et al., 1995; Rausch et al., 2002; Wu et al., 2008, 2010). We evaluated the abundance of IGFBP2 and IGBPB3 mRNA, because they are the most important in blood circulation (Kenneth, 2001). We know that IGFBP3 is the major IGFBP in serum and, in most situations, suppresses the mitogenic action of IGF-1 by forming a ternary complex involving IGF-1, IGFBP3, and an acid-labile subunit. This complex hinders IGF-1 from crossing the capillary walls to the extravascular tissue, retaining IGF-1 in the blood (McCusker, 1998; Firth and Baxter, 2002). In contrast, IGFBP2 is involved in the delivery of IGF-1 to tissues, because the interaction of IGFBP2 with IGF-1 form a smaller complex that can cross the capillary endothelium (Bar et al., 1990).
Radcliff et al. (2004) observed that changes in serum IGFBP2 were closely related to the changes in the expression of IGFBP2 mRNA in the liver. In this study, a high nutrient intake level resulted in lower expression of $I G F B P 2$, higher expression of IGFBP3, and no changes in expression of $I G F 1 R$. Daniels et al. (2008) found similar effects on circulating IGFBP2 and IGFBP3 when they increased dietary protein and energy intake in preweaned Holstein heifers. Our study revealed a significant negative correlation between serum IGF-1 and liver IGFBP2 expression, and a positive correlation between serum IGF-1 and liver IGFBP3 expression. These results suggest that a high nutrient intake increases serum IGF-1 concentration but might impair mammary parenchyma growth by elevating IGFBP3, reducing the bioavailability of IGF-1 for stimulating mammogenesis.

Heifers fed HG had lower parenchyma weight with more lipid content. Although we did not detect significant differences in the number of intraparenchymal adipocytes between the nutrient intake levels, the MA heifers had a numerically greater number of intraparenchymal adipocytes than LG and HG heifers. This can be explained by the point-counting method used to estimate the number of adipocytes and the apparent differences in adipocyte size in response to diets. Empirical observation suggests that LG and HG heifers had larger adipocytes, resulting in smaller numbers of adipocytes per area. During the postnatal stage, pre-adipocytes grow by mechanism, hyperplasia, and hypertrophy (Jo et al., 2009), and mature adipocytes are the major site for storage of excess energy in the form of triglycerides (Azain, 2003). Kadegowda et al. (2014) have reported that nutritional treatments modified the adipogenic and lipogenic capacity of steer pre-adipocytes in vitro. In accordance with that study, our results show that enhancing nutrient intake level increased lipogenesis in the parenchyma and could increase the accumulation of triglycerides into adipocytes. We attributed this response to the fact that enhancing nutrient intake to 2.5 $\times$ that of heifers fed the MA diet upregulated the genes for lipogenic enzymes such as FASN, ACCA, and CD36 (thrombospondin receptor). The FASN and $A C C A$ genes are involved in fatty acid synthesis (Martin et al., 1961; Freake and Moon, 2003), and the CD36 gene is involved in fatty acid uptake into cells (Sfeir et al., 1997). Supporting this idea, earlier studies reported that promoters of the genes for lipogenic enzymes, including those for FASN and ACCA, are regulated by dietary state and hormones (Girard et al., 1994; Hillgartner et al., 1995). For example, insulin increases transcription of these genes (Girard et al., 1994; Hillgartner et al., 1995; Freake and Moon, 2003). These previous studies corroborate our finding that enhancing nutrient intake 
leads to an altered insulin profile over the long term and can alter the extent of lipogenesis in mammary parenchyma. This point is also supported by the significant positive correlation between lipid content in the parenchyma and mammary expression of $A C C A$ and CD36 genes. Moreover, a transcriptomic study in the mammary parenchyma of preweaned heifers reported that enhancing nutrient intake to twice that of a conventional calf-rearing program increased CD36 gene expression (Piantoni et al., 2012).

Another gene upregulated by enhancing nutrient intake was $A D I P O R 1$, the receptor for adiponectin $(A D I P O Q)$. The $A D I P O Q$ pro-adipogenic factor is expressed in the mammary fat pad and is involved in the hypertrophy of adipocytes (Lefterova and Lazar, 2009). Considering that ADIPOR1 was upregulated by high nutrient intake, we can hypothesize (although not confirm) that adiponectin secreted from the mammary fat pad could be involved in the increased size of intraparenchymal adipocytes by accumulation of triglycerides. Future studies evaluating adiponectin expression in response to nutritional treatment will be required to confirm this hypothesis.

Our study is the first to reveal differential gene expression over time induced by nutrition in heifers' mammary parenchyma. Expression of $C D 36, A C C A$, $F A S N$, and ADIPOR 1 was more responsive to dietary manipulation at $42 \mathrm{~d}$ of the initial experiment than at $84 \mathrm{~d}$. Further studies are needed to better understand the mechanisms underlying this change in mammary expression.

\section{CONCLUSIONS}

Enhancing nutrient intake in prepubertal Holstein $\times$ Gyr heifers altered mammary development. Observed changes likely depended on systemic insulin and IGF1 , as well as on liver $G H R$, IGF1, and IGFBP3 gene expression and downstream activity. Our data demonstrated that enhanced nutrient intake increased body fat and mammary fat accumulation and seemed to compromise parenchyma growth. Also, the increase in mRNA expression of lipogenic enzymes in parenchyma following increased nutrient intake suggested adipocyte hypertrophy in the mammary parenchyma of HG heifers compared with the other groups. Further research in crossbred prepubertal heifers is required to determine the best ADG to accelerate growth rates without negative effects on mammary growth and milk yield.

\section{ACKNOWLEDGMENTS}

The authors gratefully acknowledge Conselho Nacional de Desenvolvimento Científico e Tecnológico (CNPq,
Brazil), Fundação de Amparo à Pesquisa do estado de Minas Gerais (FAPEMIG, Brazil), Instituto Nacional de ciência e Tecnologia de ciência animal (INCT-CA, Brazil), and Coordenação de Aperfeiçoamento de Pessoal de Nível Superior (CAPES, Brazil; Project PVE A125/2013).

\section{REFERENCES}

AOAC. 1990. Official Methods of Analysis. 15th ed. AOAC, Washington, DC.

Azain, M. J. 2003. Conjugated linoleic acid and its effects on animal products and health in single-stomached animals. Proc. Nutr. Soc. 62:319-328.

Bar, R. S., D. R. Clemmons, M. Boes, W. H. Busby, B. A. Booth, B. L. Dake, and A. Sandra. 1990. Transcapillary permeability and subendothelial distribution of endothelial and amniotic fluid insulinlike growth factor binding proteins in the rat heart. Endocrinology 127:1078-1086.

Block, S. S., J. M. Smith, R. A. Ehrhardt, M. C. Diaz, R. P. Rhoads, M. E. Van Amburgh, and Y. R. Boisclair. 2003. Nutritional and developmental regulation of plasma leptin in dairy cattle. J. Dairy Sci. 86:3206-3214.

Bustin, S. A., V. Benes, J. A. Garson, J. Hellemans, J. Huggett, M. Kubista, R. Mueller, T. Nolan, M. W. Pfaffl, G. L. Shipley, J. Vandesompele, and C. T. Wittwer. 2009. The MIQE guidelines: Minimum information for publication of quantitative realtime PCR experiments. Clin. Chem. 55:611-622. http://dx.doi. org/10.1373/clinchem.2008.112797.

Butler, S. T., A. L. Marr, S. H. Pelton, R. P. Radcliff, M. C. Lucy, and W. R. Butler. 2003. Insulin restores GH responsiveness during lactation-induced negative energy balance in dairy cattle: Effects on expression of IGF-1 and GH receptor 1A. J. Endocrinol. 176:205-217.

Capuco, A. V., J. J. Smith, D. R. Waldo, and C. E. Rexroad Jr. 1995. Influence of prepubertal dietary regimen on mammary growth of Holstein heifers. J. Dairy Sci. 78:2709-2725.

Daniels, K. M., S. R. Hill, K. F. Knowlton, R. E. James, M. L. McGilliard, and R. M. Akers. 2008. Effects of milk replacer composition on selected blood metabolites and hormones in preweaned Holstein heifers. J. Dairy Sci. 91:2628-2640.

Davis Rincker, L. E. 2005. Nutritional influences on body and mammary gland growth and regulation of leptin and IGF1 in prepubertal dairy heifers. PhD Thesis. Michigan State Univ., East Lansing.

Delavaud, C., F. Bocquier, Y. Chilliard, D. H. Keisler, A. Gertler, and G. Kann. 2000. Plasma leptin determination in ruminants: Effect of nutritional status and body fatness on plasma leptin concentration assessed by a specific RIA in sheep. J. Endocrinol. 165:519-526.

Delavaud, C., A. Ferlay, Y. Faulconnier, F. Bocquier, G. Kann, and Y. Chilliard. 2002. Plasma leptin concentration in adult cattle: Effects of breed, adiposity, feeding level, and meal intake. J. Anim. Sci. 80:1317-1328.

Eleswarapu, S., Z. Gu, and H. Jiang. 2008. Growth hormone regulation of insulin like growth factor-I gene expression may be mediated by multiple distal signal transducer and activator of transcription 5 binding sites. Endocrinology 149:2230-2240.

Embrapa Gado de Leite. 2005. Sistema de produção. Accessed Feb. 5, 2016. https://sistemasdeproducao.cnptia.embrapa.br/ FontesHTML/Leite/LeiteRecriadeNovilhas/racas.htm.

Farr, V. C., K. Stelwagen, L. R. Cate, A. J. Molenaar, T. B. McFadden, and S. R. Davis Sr.. 1996. An improved method for the routine biopsy of bovine mammary tissue. J. Dairy Sci. 79:543-549.

Firth, S. M., and R. C. Baxter. 2002. Cellular action of insulin-like growth factor binding proteins. Endocr. Rev. 23:824-854.

Forsyth, I. A. 1996. The insulin-like growth factor and epidermal growth factor families in mammary cell growth in ruminants: Action and interaction with hormones. J. Dairy Sci. 79:1085-1096. 
Freake, H. C., and Y. K. Moon. 2003. Hormonal and nutritional regulation of lipogenic enzyme mRNA levels in rat primary white and brown adipocytes. J. Nutr. Sci. Vitaminol. (Tokyo) 49:40-46.

Girard, J., D. Perdereau, F. Foufelle, C. Prip-Buus, and P. Ferre. 1994. Regulation of lipogenic enzyme gene expression by nutrients and hormones. FASEB J. 8:36-42.

Hillgartner, F. B., L. Salati, and A. Goodridge. 1995. Physiologic and molecular mechanisms involved in nutritional regulation of fatty acid synthesis. Physiol. Rev. 75:47-76.

Jo, J., O. Gavrilova, S. Pack, W. Jou, S. Mullen, A. E. Sumner, S. W. Cushman, and V. Periwal. 2009. Hypertrophy and/or hyperplasia: Dynamics of adipose tissue growth. PLOS Comput. Biol. 5:e1000324.

Kadegowda, A. K. G., A. Wright, and S. K. Duckett. 2014. Nutritional milieu of isolated stromal vascular cells determines their proliferative, adipogenic, and lipogenic capacity in vitro. Adipocyte 3:304-313.

Kenneth, L. B. 2001. Growth hormone and disorders. Pages 957-959 in Principles and Practice of Endocrinology and Metabolism. 3rd ed. Lippincott Williams and Wilkins, Philadelphia, PA.

Lefterova, M. I., and M. A. Lazar. 2009. New development in adipogenesis. Trends Endocrinol. Metab. 20:107-114.

Livak, K. J., and T. D. Shmittgen. 2001. Analysis of relative expression data using real time quantitative PCR and the $2-\Delta \Delta \mathrm{Ct}$ method. Methods 25:402-408.

Martin, D. B., M. G. Horning, and P. R. Vagelos. 1961. Fatty acid synthesis in adipose tissue. I. Purification and properties of a long chain fatty acid-synthesizing system. J. Biol. Chem. 236:663-668.

McCusker, R. H. 1998. Controlling insulin-like growth factor activity and the modulation of insulin-like growth factor binding protein and receptor binding. J. Dairy Sci. 81:1790-1800.

Meyer, M. J., R. P. Rhoads, A. V. Capuco, E. E. Connor, A. Hummel, Y. R. Boisclair, and M. E. Van Amburgh. 2007. Ontogenic and nutritional regulation of steroid receptor and IGF-I transcript abundance in the prepubertal heifer mammary gland. J. Endocrinol. 195:59-66.

NRC. 2001. Nutrient Requirements of Dairy Cattle. 7th rev. ed. Natl. Acad. Press, Washington, DC.

Pearson, E. G., and A. M. Craig. 1980. The diagnosis of liver disease in equine and food animals: Part I. Mod. Vet. Pract. 61:315-320.

Phillips, L. S., S. Goldstein, and C. I. Pao. 1991. Nutrition and somatomedin XXVI. Molecular regulation of IGF-I by insulin in cultured rat hepatocytes. Diabetes 40:1525-1530.

Piantoni, P., M. Bionaz, D. E. Graugnard, K. M. Daniels, R. M. Akers, and J. J. Loor. 2008. Gene expression ratio stability evaluation in prepubertal bovine mammary tissue from calves fed different milk replacers reveals novel internal controls for quantitative polymerase chain reaction. J. Nutr. 138:1158-1164.

Piantoni, P., M. K. Daniels, R. E. Everts, S. L. Rodriguez-Zas, H. A. Lewin, W. L. Hurley, R. M. Akers, and J. J. Loor. 2012. Level of nutrient intake affects mammary gland gene expression profiles in preweaned Holstein heifers. J. Dairy Sci. 95:2550-2561.

Purup, S., M. Vestergaard, and K. Sejrsen. 2000a. Involvement of growth factors in the regulation of pubertal mammary growth in cattle. Adv. Exp. Med. Biol. 480:27-43.

Purup, S., M. Vestergaard, M. S. Weber, K. Plaut, R. M. Akers, and K. Sejrsen. 2000b. Local regulation of pubertal mammary growth in heifers. J. Anim. Sci. 78(Suppl. 3):36-47.

Radcliff, R. P., B. L. McCormack, B. A. Crooker, and M. C. Lucy. 2003. Growth hormone (GH) binding and expression of GH receptor 1A mRNA in hepatic tissue of periparturient dairy cows. J. Dairy Sci. 86:3933-3940.

Radcliff, R. P., M. J. VandeHaar, Y. Kobayashi, B. K. Sharma, H A. Tucker, and M. C. Lucy. 2004. Effect of dietary energy and somatotropin on components of the somatotropic axis in Holstein heifers. J. Dairy Sci. 87:1229-1235.

Radcliff, R. P., M. J. VandeHaar, A. L. Skidmore, L. T. Chapin, B. R. Radke, J. W. Lloyd, E. P. Stanisiewski, and H. A. Tucker. 1997. Effects of diet and bovine somatotropin on heifer growth and mammary development. J. Dairy Sci. 80:1996-2003.
Rausch, M. I., M. W. Tripp, K. E. Govoni, W. Zang, W. J. Weber, B. A. Crooker, T. A. Hoagland, and S. A. Zinn. 2002. The influence of level of feeding on growth and serum insulin-like growth factor I and insulin-like growth factor-binding proteins in growing beef cattle supplemented with somatotropin. J. Anim. Sci. 80:94-100.

Schwartzbauer, G., and R. K. Menon. 1998. Regulation of growth hormone receptor gene expression. Mol. Genet. Metab. 63:243-253.

Sejrsen, K., J. T. Huber, and H. A. Tucker. 1983. Influence of amount fed on hormone concentrations and their relationship to mammary growth in heifers. J. Dairy Sci. 66:845-855.

Sejrsen, K., J. T. Huber, H. A. Tucker, and R. M. Akers. 1982. Influence of nutrition of mammary development in pre- and postpubertal heifers. J. Dairy Sci. 65:793-800.

Sejrsen, K., S. Purup, M. Vestergaard, and J. Foldager. 2000. High body weight gain and reduced bovine mammary growth: Physiological basis and implications for milk yield potential. Domest. Anim. Endocrinol. 19:93-104.

Sfeir, Z., A. Ibrahimi, E. Amri, P. Grimaldi, and N. Abumrad. 1997. Regulation of FAT/CD36 gene expression: Further evidence in support of a role of the protein in fatty acid binding/transport. Prostaglandins Leukot. Essent. Fatty Acids 57:17-21.

Shao, Y., E. H. Wall, T. B. McFadden, Y. Misra, X. Qian, R. Blauwiekel, D. Kerr, and F. Q. Zhao. 2013. Lactogenic hormones stimulate expression of lipogenic genes but not glucose transporters in bovine mammary gland. Domest. Anim. Endocrinol. 44:57-69.

Sharma, B. K., M. J. VandeHaar, and N. K. Ames. 1994. Expression of insulin-like growth factor-I in cows at different stages of lactation and in late lactation cows treated with somatotropin. J. Dairy Sci. $77: 2232-2241$.

Silva, L. F., M. J. VandeHaar, M. S. Weber Nielsen, and G. W. Smith 2002. Evidence for a local effect of leptin in bovine mammary gland. J. Dairy Sci. 85:3277-3286.

Smith, J. M., M. E. VanAmburgh, M. C. Diaz, M. C. Lucy, and D. E. Bauman. 2002. Effect of nutrient intake on the development of somatotropic axis and its responsiveness to GH in Holstein bull calves. J. Anim. Sci. 80:1528-1537.

Smith, W. J., L. E. Underwood, and D. R. Clemmons. 1995. Effects of caloric or protein restriction on insulin-like growth factor-I (IGF-I) and IGF-binding proteins in children and adults. J. Clin. Endocrinol. Metab. 80:443-449.

Stelwagen, K., and D. G. Grieve. 1990. The effects of plane of nutritional on growth ad mammary gland development in Holstein heifers. J. Dairy Sci. 73:2333-2341.

Swanson, E. W. 1960. Effect of rapid growth with fattening of dairy heifers on their lactational ability. J. Dairy Sci. 43:377.

Thorn, S. R., S. Purup, W. S. Cohick, M. Vestergaard, K. Sejrsen, and Y. R. Boisclair. 2006. Leptin does not act directly on mammary epithelial cells in prepubertal dairy heifers. J. Dairy Sci. 89:1467-1477.

Vandesompele, J., K. De Preter, F. Pattyn, B. Poppe, N. Van Roy, A. De Paepe, and F. Speleman. 2002. Accurate normalization of real-time quantitative RT-PCR data by geometric averaging of multiple internal control genes. Genome Biol. 3:RESEARCH0034.

Weber, M. S., S. Purup, M. Vestergaard, S. E. Ellis, J. SondergardAndersen, R. M. Akers, and K. Sejrsen. 1999. Contribution of insulin-like growth factor (IGF)-I and IGF-binding protein-3 to mitogenic activity in bovine mammary extracts and serum. J. Endocrinol. 161:365-373.

Wu, M., J. B. Hall, R. M. Akers, and H. Jiang. 2010. Effect of feeding level on serum IGF1 response to GH injection. J. Endocrinol. 206:37-45.

Wu, M., A. Wang, G. C. Bernard, J. B. Hall, W. E. Beal, R. M. Akers, Y. R. Boisclair, and H. Jiang. 2008. Increased degradation of insulin-like growth factor-I in serum from feed-deprived steers. Domest. Anim. Endocrinol. 35:343-351.

Yakar, S., J. L. Liu, B. Stannard, A. Butler, D. Accili, B. Sauer, and D. LeRoith. 1999. Normal growth and development in the absence of hepatic insulin-like growth factor I. Proc. Natl. Acad. Sci. USA 96:7324-7329. 